\title{
ANALISIS KEMANFAATAN NPWP,KUALITAS PELAYANAN, DAN SANKSI PAJAK SERTA PENGARUHNYA TERHADAP KEPATUHAN WAJIB PAJAK ORANG PRIBADI YANG TERDAFTAR DI KPP PRATAMA CIBITUNG DENGAN PERAN ACCOUNT REPRESENTATIVE SEBAGAI VARIABEL MODERASI
}

\author{
Dian Sulistyorini Wulandari \\ Universitas Pelita Bangsa \\ diansulis1845@gmail.com
}

\begin{abstract}
ABSTRAK - Penelitian ini bertujuan untuk menguji pengaruh kemanfaatan NPWP, kualitas pelayanan, dan sanksi pajak terhadap kepatuhan wajib pajak dengan peran account representative sebagai variabel moderasi. Penelitian ini merupakan penelitian kuantitatif dengan pendekatan deskriptif. Populasi dalam penelitian ini adalah seluruh wajib pajak yang berada di Kantor Pelayanan Pajak (KPP) Pratama Cibitung. Teknik pengambilan sampel menggunakan purposive sampling. Sampel di dalam penelitian ini adalah wajib pajak yang berada pada di Kantor Pelayanan Pajak (KPP) Pratama Cibitung. Data yang digunakan dalam penelitian ini merupakan data primer yang dikumpulkan melalui survei kuesioner secara langsung. Pengumpulan data dilakukan dengan menyebar 100 kuesioner kepada responden. Analisis data menggunakan analisis regresi linear berganda dan analisis regresi moderating dengan pendekatan nilai selisih mutlak. Analisis regresi linear berganda untuk hipotesis kemanfaatan NPWP, kualitas pelayanan, dan sanksi pajak. Analisis regresi linear berganda dengan nilai uji selisih mutlak untuk hipotesis kemanfaatan NPWP, kualitas pelayanan, dan sanksi pajak yang dimoderasi oleh peran account representative. Hasil penelitian dengan analisis regresi linear berganda menunjukkan bahwa kemanfaatan NPWP, kualitas pelayanan, dan sanksi pajak berpengaruh positif dan signifikan terhadap kepatuhan wajib pajak. Analisis variabel moderating degan selisih mutlak menunjukkan bahwa peran account representative tidak dapat memoderasi kemanfaatan NPWP dan sanksi pajak terhadap kepatuhan wajib pajak tetapi dapat memoderasi kualitas pelayanan terhadap kepatuhan wajib pajak.
\end{abstract}

Kata Kunci : Kemanfaatan NPWP, Kualitas Pelayanan, Sanksi Perpajakan, Peran Account Representative dan Kepatuhan Wajib Pajak

ABSTRACT - This study aims to examine the effect of the benefits of NPWP, service quality, and tax sanctions on taxpayer compliance with account representative performance as a moderating variable. This research is quantitative research with a descriptive approach. The population in this study are all taxpayers who are in the Tax Office (KPP) Pratama Cibitung. The sampling technique uses purposive sampling. The sample in this study is the taxpayer who is at the Tax Office (KPP) Pratama Cibitung. The data used in this study are primary data collected through a questionnaire survey directly. Data collection was carried out by distributing 100 
questionnaires to respondents. Data analysis uses multiple linear regression analysis and moderating regression analysis with the absolute difference value approach. Multiple linear regression analysis for the hypothesis of the benefit of NPWP, service quality, and tax sanctions. Multiple linear regression analysis with absolute difference test values for the hypothesis of the benefits of NPWP, service quality, and tax sanctions that are moderated by the performance of account representatives. The results of research with multiple linear regression analysis show that the benefits of NPWP, service quality and tax sanctions have a positive and significant effect on taxpayer compliance. Analysis of moderating variables with absolute difference shows that account representative performance cannot moderate the benefits of NPWP and tax sanctions on taxpayer compliance but can moderate the quality of service to taxpayer compliance.

Keywords:Utilization of NPWP, Service Quality, Tax Sanctions, Account representative Performance, and Taxpayer Compliance

\section{PENDAHULUAN}

Tujuan yang ingin dicapai oleh pemerintah Indonesia yang tercantum dalam pembukaan undang-undang dasar negara Indonesia 1945 salah satunya adalah memajukan kesejahteraan umum. Kesejahteraan untuk rakyat Indonesia dapat diwujudkan dengan jalannya kegiatan pemerintahan yang baik, memperhatikan keadaan ekonomi penduduk serta adanya pembangunan yang berkesinambungan di seluruh bidang, untuk itu diperlukan sumber pembiayaan yang memadai. Pajak sebagai sumber Anggaran Pendapatan Belanja Negara (APBN) yang terbesar saat ini, hampir $75 \%$ sumber APBN negara Indonesia berasal dari pajak, oleh karena itu menurut Resmi (2016) pajak dianggap sebagai fungsi budgeter yang membiayai pengeluaran pemerintah baik pengeluaran rutin maupun pembangunan.

Pada saat ini pajak memberikan peran yang sangat penting untuk negara, terutama dalam membiayai pembangunan nasional. Peranan pajak yang tidak dapat tergantikan oleh sumber-sumber penerimaan negara lainnya seperti penerimaan bukan pajak bahkan dengan hutang sekalipun yang membuat pemerintah Indonesia menggencarkan kegiatan-kegiatan yang dapat meningkatkan penerimaan pajak sesuai dengan target yang diharapkan. Untuk dapat melihat besarnya peranan pajak dalam penerimaan dalam negeri, dibandingkan dengan jenis-jenis penerimaan bukan pajak maka disajikan tabel dibawah yang menyajikan data persentase realisasi penerimaan negara dari sektor pajak dan bukan pajak untuk 3 tahun terakhir.

Tabel 1 Persentase realisasi penerimaan Negara dari sektor pajak dan bukan pajak dalam APBN (miliar rupiah)

\begin{tabular}{|c|c|c|}
\hline Sumber penerimaan & 2016 & 2017 \\
\hline $\begin{array}{l}\text { I. Penerimaan Dalam Negeri } \\
\text { Penerimaan perpajakan } \\
\text { Pajak Dalam Negeri } \\
\text { Pajak Penghasilan } \\
\text { Pajak Pertambahan nilai } \\
\text { Pajak Bumi dan } \\
\text { Bangunan } \\
\text { Bea perolehan hak atas } \\
\text { tanah \& bangunan } \\
\text { Cukai } \\
\text { Pajak lainnya } \\
\text { Pajak Perdagangan } \\
\text { internasional } \\
\text { Bea Masuk } \\
\text { Pajak Ekspor }\end{array}$ & $\begin{array}{l}\mathbf{1 , 7 8 4 , 2 4 9 . 7 0} \\
\mathbf{1 , 4 9 5 , 8 9 3 . 8 0} \\
1,461,818.70 \\
784,726.90 \\
493,888.70 \\
17,295.60 \\
0 \\
157,158.00 \\
8.749 .60 \\
34,075.10 \\
33,735.00 \\
340.10\end{array}$ & $\begin{array}{l}\mathbf{1 , 7 3 6 , 2 5 6 . 7 0} \\
\mathbf{1 , 4 9 5 , 8 9 3 . 8 0} \\
1,461,818.70 \\
784,726.90 \\
493,888.70 \\
17,295.60 \\
0 \\
157,158.00 \\
8,749.60 \\
34,075.10 \\
33,375.00 \\
340.10\end{array}$ \\
\hline $\begin{array}{l}\text { Penerimaan Bukan Pajak } \\
\text { Penerimaan Sumber Daya } \\
\begin{array}{l}\text { Alam } \\
\text { Bagian laba BUMN }\end{array} \\
\begin{array}{l}\text { Penerimaan Bukan } \\
\text { Lainnya }\end{array} \\
\begin{array}{l}\text { Pendapatan } \\
\text { Layanan Umum }\end{array} \\
\end{array}$ & $\begin{array}{l}\mathbf{2 4 5 , 0 8 3 . 6 0} \\
90,524.30 \\
34,164.00 \\
84,124.00 \\
36,271.20\end{array}$ & $\begin{array}{l}\mathbf{2 4 0 , 3 6 2 . 9 0} \\
80,273.90 \\
38,000.00 \\
84,430.70 \\
37,658.30\end{array}$ \\
\hline II Hibah & \begin{tabular}{l|}
$1,975.20$ \\
$1,786,225.00$
\end{tabular} & \begin{tabular}{|l|}
$1,372.70$ \\
$1,737,629.40$
\end{tabular} \\
\hline
\end{tabular}

(Sumber : www.bps.go.id, 2019) 
Dilihat dari tabel di atas efektivitas penerimaan pajak masih belum stabil masih ada kenaikan dan penurunan setiap tahun. Hal tersebut menunjukkan bahwa pemerintah kurang optimal dalam penyerapan penerimaan perpajakan, dalam hal ini seharusnya pemerintah meningkatkan kinerja khususnya fiskus agar penerimaan dari perpajakan dapat optimal.

Wajib pajak mempunyai kewajiban untuk mendaftarkan dirinya untuk memperoleh Nomor Pokok Wajib Pajak (NPWP), dimana NPWP ini berfungsi sebagai alat identitas wajib pajak dalam administrasi perpajakan, satu wajib pajak hanya mempunyai satu nomor NPWP yang berfungsi untuk menertibkan dan memudahkan wajib pajak untuk melakukan pembayaran dan pelaporan pajaknya (Halim dkk, 2016). Bahkan Resmi (2011) berpendapat adanya manfaat yang diberikan kepada wajib pajak terkait kepemilikan NPWP ini diantara-Nya adalah sebagai salah satu syarat dalam pembukaan rekening koran dan dalam mengajukan kredit di bank. Selain itu NPWP bermanfaat untuk mengurus Surat Izin Usaha Perdagangan (SIUP) dan untuk membayar pajak dimuka (angsuran/kredit pajak) atas Fiskal Luar Negeri ketika wajib pajak ditolak keluar negeri (Halim dkk, 2016).

Aparatur pajak telah memberikan banyak manfaat ketika memiliki Nomor Pokok Wajib Pajak (NPWP) kepada wajib pajak, oleh karena itu kepemilikan ini diwajibkan dan wajib pajak termotivasi tidak hanya untuk memiliki NPWP tersebut tetapi juga termotivasi dalam memenuhi kewajiban perpajakannya (Masruroh, 2013). Sistem pemungutan pajak di Indonesia mengenal adanya system Self Assessment, dimana dalam sistem ini wajib pajak bertindak aktif dalam menghitung, menyetor dan melapor. Kepemilikan NPWP ini sebagai wujud pelaksanaan dalam system self assessment. Oleh karena itu kemanfaatan NPWP (Nomor Pokok Wajib Pajak) diduga sebagai salah satu faktor yang dapat mempengaruhi kepatuhan wajib pajak dalam membayarkan dan melaporkan pajaknya.

Wajib pajak yang terdaftar saat ini pada Direktorat Jendral Pajak (DJP) menurut www.pajak.go.id berjumlah 36.031.972 dan 16.599.632 diantara-Nya wajib menyampaikan SPT. Dari jumlah wajib pajak yang terdaftar tersebut yang telah menyampaikan SPT tahun pajak 2016 adalah 9.789.398 atau sekitar $58,97 \%$. Jika disandingkan dengan data jumlah penduduk Indonesia yang disampaikan oleh Kementerian Dalam Negeri bahwa jumlah penduduk Indonesia per 18 September 2017 yang telah memiliki Kartu Tanda Penduduk elektronik (E-KTP) sebanyak 175.949.127. Jika diasumsikan bahwa jumlah tersebut adalah jumlah orang dewasa yang berpenghasilan (aktif maupun pasif) dan yang tidak berpenghasilan, sehingga dapat disimpulkan hanya 36.031.972 dari 175.949.127 penduduk atau hanya sekitar $0,21 \%$ penduduk yang ber E-KTP yang memiliki NPWP. Adapun data perbandingan jumlah tenaga kerja dan jumlah wajib pajak yang terdaftar di KPP Pratama Cibitung pada tahun 2013-2015 disajikan pada tabel berikut ini :

Tabel 2 Jumlah tenaga kerja Kabupaten Cibitung \& Jumlah Wajib Pajak terdaftar di KPP Pratama Cibitung

\begin{tabular}{|c|c|c|}
\hline Tahun & $\begin{array}{c}\text { Jumlah tenaga } \\
\text { kerja di } \\
\text { Kabupaten } \\
\text { Cibitung }\end{array}$ & $\begin{array}{c}\text { Jumlah Wajib } \\
\text { Pajak terdaftar } \\
\text { di KPP Cibitung }\end{array}$ \\
\hline 2013 & 1.268 .648 & 237.684 \\
\hline 2014 & 1.295 .522 & 266.011 \\
\hline 2015 & 1.334 .821 & 291.603 \\
\hline
\end{tabular}

(Sumber : KPP Pratama Cibitung, 2019) 
Berdasarkan tabel diatas terdapat selisih yang cukup jauh antara jumlah tenaga kerja dengan jumlah wajib pajak yang terdaftar ber NPWP di KPP Pratama Cibitung. Berdasarkan data di atas dapat dilihat bahwa masih kurangnya kesadaran dan partisipasi masyarakat dalam memenuhi kewajibankewajiban perpajakan yang harus dipenuhi dalam sistem administrasi perpajakan yang berlaku.

Peraturan pajak yang semakin berkembang dan selalu mengalami perubahan, menuntut wajib pajak untuk selalu mengikuti peraturan pajak tersebut. Untuk memaksimalkan pemahaman wajib pajak perlu ditingkatkan fungsi pelayanan. Kantor Pelayanan Pajak sebagai tempat yang melakukan pelayanan langsung kepada wajib pajak, dituntut adanya pelayanan yang prima dari para fiskus dan pegawainya supaya wajib pajak dapat menjalani kewajiban perpajakannya dengan baik.

Salah satu cara untuk meningkatkan kepatuhan wajib pajak yaitu dengan memberikan pelayanan pajak yang baik kepada wajib pajak (Masruroh, 2013). Adapun penelitian yang mendukung hal diatas adalah penelitian oleh Fuadi (2013) yang berpendapat bahwa kualitas pelayanan petugas pajak berpengaruh signifikan terhadap kepatuhan wajib pajak Usaha Mikro, Kecil dan Menengah (UMKM) di Jawa Timur. Kualitas pelayanan harus selalu ditingkatkan untuk meningkatkan kepatuhan dan kepuasan wajib pajak.

Banyak faktor yang dapat mempengaruhi kepatuhan wajib pajak salah satunya dengan sanksi pajak. Sanksi pajak ini dapat berupa adanya penegakan hukum perpajakan yang tegas kepada wajib pajak yang tidak menjalankan kewajiban pajaknya, seperti masih banyak wajib pajak yang terlambat membayarkan dan melapor pajak yang menjadi kewajibannya. Peraturan perpajakan terdiri atas undang-undang yang mengatur tentang ketentuan umum dan tata cara perpajakan, peraturan perpajakan tersebut agar dipatuhi harus diterapkan adanya sanksi pajak. Adapun usaha aparatur pajak dalam pencapaian tujuan perpajakan itu sendiri tidak selalu lancar. Wajib pajak mempunyai banyak alasan untuk tidak membayar atau tidak melaporkan kewajiban perpajakannya kepada petugas pajak salah satunya adalah adanya sanksi pajak yang dikenakan kepada wajib pajak yang melanggar peraturan perpajakan yang dianggap memberatkan wajib pajak.

Fenomena perpajakan yang berkembang di Indonesia adalah banyak wajib pajak yang melaporkan pajak yang tidak sebenarnya, hal ini didasarkan dengan adanya kebijakan fiskus pajak yaitu sunset policy yang dilakukan pada tahun 2008 dan juga tax amnesty pada tahun 2016 dan juga tahun 2017. Sunset policy sendiri yaitu kebijakan pemberian fasilitas perpajakan dalam bentuk penghapusan sanksi administrasi perpajakan berupa bunga yang diatur dalam Pasal 37A Undang-Undang Ketentuan Umum dan Tata Cara Perpajakan (Undang-Undang Nomor 28 Tahun 2007), Sedangkan Tax Amnesty sebuah kesempatan berbatas waktu bagi kelompok wajib pajak tertentu sebagai pengampunan atas kewajiban membayar pajak (termasuk dihapuskannya bunga denda) yang berkaitan dengan masa pajak sebelumnya tanpa takut penuntutan pidana. Pada tahun ini, wajib pajak seperti mendapat pengampunan atas kelalaian mereka dalam melaporkan pajak seperti kurang bayar dan tidak bayar. Fenomena tersebut diatas menjadi bukti bahwa wajib pajak tidak melaporkan pajak karena memiliki ketakutan terhadap sanksi yang akan diterima apabila melanggar peraturan pajak. 
Sanksi perpajakan menurut undang-undang Pasal 7 Nomor 28 Tahun 2007 tentang ketentuan umum perpajakan (KUP) terdiri dari sanksi administrasi dan sanksi pidana, untuk sanksi administrasi terdiri dari denda, sanksi bunga, dan sanksi kenaikan. Sanksi berupa bunga sebesar $2 \%$ per bulan, sanksi denda administrasi mulai dari Surat Tagihan Pajak (STP) ditambah Rp50.000,00 sampai dengan Rp100.000,00 serta Surat Setoran Pajak (SSP) ditambah $200 \%$, dan sanksi berupa kenaikan $50 \%$ dan $100 \%$. Untuk sanksi pidana dapat berupa denda pidana, pidana kurungan, serta pidana penjara. Pemberlakuan sanksi perpajakan mempunyai tujuan untuk memberikan efek jera kepada wajib pajak yang melanggar norma perpajakan sehingga tercipta kepatuhan wajib pajak dalam melaksanakan kewajiban perpajakannya.

Aparatur pajak menerapkan sanksi pajak hanya untuk meningkatkan kepatuhan wajib pajak dalam menghitung, menyetor dan melapor sendiri kewajiban perpajakannya sesuai dengan system self assessment yang diterapkan di Indonesia (Adrianti, Wella, 2013). Adapun jumlah wajib pajak yang telah melaporkan pajak tahunannya di KPP Pratama Cibitung :

Tabel 3 Jumlah Wajib Pajak yang telah melaporkan Pajak tahunannya di KPP Pratama Cibitung

\begin{tabular}{|l|c|c|c|}
\hline \multicolumn{1}{|c|}{ Tahun } & $\mathbf{2 0 1 6}$ & $\mathbf{2 0 1 7}$ & $\mathbf{2 0 1 8}$ \\
\hline $\begin{array}{l}\text { Realisasi } \\
\text { SPT }\end{array}$ & 85.113 & 80.654 & 80.545 \\
\hline Badan & 2.758 & 3.474 & 3.496 \\
\hline $\begin{array}{l}\text { Op non } \\
\text { karyawan }\end{array}$ & 1.756 & 2.510 & 2.204 \\
\hline $\begin{array}{l}\text { Op } \\
\text { karyawan }\end{array}$ & 80.599 & 74.670 & 74.845 \\
\hline
\end{tabular}

(Sumber : KPP Pratama Cibitung, 2019)

Tabel diatas menjelaskan bahwa terdapat kenaikan dan penurunan kepatuhan wajib pajak dalam memenuhi kewajibannya perpajakannya. Wajib pajak yang tidak mempunyai pengetahuan dan pemahaman perpajakan yang cukup dapat menimbulkan ketidakpatuhan sehingga wajib pajak secara tidak sengaja melakukan hal-hal yang melanggar kewajiban perpajakannya, seperti tidak mendaftarkan diri untuk memperoleh Nomor Pokok Wajib Pajak (NPWP), tidak melaporkan Surat Pemberitahuan (SPT) dan para wajib pajak melakukan kewajiban perpajakan tidak sepenuhnya benar, seperti tidak membayar dan melaporkan pajak tidak sesuai dengan tarif pajak yang berlaku (Mulyanti \& Febby Sry Sugiharty, 2016).

Untuk meningkatkan kualitas pelayanan dan kepatuhan wajib pajak, maka Direktorat Jenderal Pajak mengupayakan penerapan modernisasi administrasi perpajakan. Suyanto (2017) berpendapat Modernisasi administrasi perpajakan memberikan banyak perubahan mendasar seperti restrukturisasi organisasi sampai dengan pengembangan sumber daya manusia serta penggunaan teknologi informasi dalam administrasi perpajakan. Dalam system modernisasi perpajakan, Kantor Pelayanan Pajak Modern harus melakukan proses pengelompokan potensi pajak berdasar keunggulan fiskus diwilayah wajib pajak atau mapping dan pembuatan profil wajib pajak, dimana dibutuhkan Account Representative dalam pembuatan profil tersebut yang dituntut untuk lebih dekat, lebih mengenal, dan lebih mengetahui akan kondisi Wajib Pajaknya.

Account Representative pada Kantor Pelayanan Pajak diatur dalam Keputusan Menteri Indonesia Nomor: 79/PMK.01/2015 menerangkan Account Representative merupakan salah satu ujung tombak penggalian potensi penerimaan Negara dibidang perpajakan 
yang mengemban tugas intensifikasi perpajakan melalui pemberian bimbingan/ himbauan, konsultasi, analisis dan pengawasan terhadap wajib pajak (Widomoko, 2017). Tugas Account Representative lainnya adalah untuk memberikan pengawasan yang intensif kepada wajib pajak. Untuk menopang penerapan system self assessment di Indonesia maka sangat diperlukan peran Account Representative (Irawan, 2013).

Berdasarkan uraian di atas maka penulis tertarik untuk melakukan penelitian yang menganalisis pengaruh Kebermanfaatan NPWP, Kualitas Pelayanan, dan Sanksi Pajak Terhadap Kepatuhan Wajib Pajak Orang Pribadi Yang Terdaftar di KPP Pratama Cibitung Dengan Account Representative Sebagai Variabel Moderasi.

\section{TINJAUAN PUSTAKA}

\section{Kepatuhan Wajib Pajak}

Kepatuhan wajib pajak merupakan pemenuhan kewajiban perpajakan yang dilakukan oleh wajib pajak dalam rangka pemberian kontribusi bagi pembangunan Negara yang diharapkan dalam pemenuhannya dilakukan secara sukarela. Kepatuhan wajib pajak menjadi aspek penting mengingat sistem perpajakan di Indonesia menganut sistem self Assessment di mana dalam prosesnya mutlak memberikan kepercayaan kepada wajib pajak untuk menghitung, membayar dan melaporkan kewajibannya (Tiraada, 2013).

Dalam pajak, aturan yang berlaku adalah Undang-Undang Perpajakan. Jadi, kepatuhan pajak adalah kepatuhan seseorang terhadap Undang-Undang Perpajakan. Tuntutan kepatuhan bagi wajib pajak orang pribadi telah diatur dalam Undang-Undang Nomor 16 Tahun 2000 tentang Ketentuan Umum dan Tata Cara perpajakan. Pasal 12 dalam Undang-Undang Nomor 16 Tahun 2000
Menjelaskan keharusan Wajib Pajak membayar pajak sebagai berikut: " (1) Setiap Wajib Pajak wajib membayar pajak yang terhutang berdasarkan ketentuan peraturan perundangundangan perpajakan, dengan tidak menggantungkan pada adanya surat ketetapan pajak. (2) Jumlah pajak yang terhutang menurut Surat Pemberitahuan yang disampaikan Oleh Wajib Pajak adalah jumlah pajak yang terhutang menurut ketentuan perundang-undangan perpajakan"

Kepatuhan Wajib Pajak menurut Purnaditya (2015) merupakan pemenuhan kewajiban perpajakan yang dilakukan oleh pembayar pajak dalam rangka memberikan kontribusi bagi pembangunan negara yang diharapkan di dalam pemenuhannya dilakukan secara sukarela. Kepatuhan Wajib Pajak menjadi sangat penting ketika di Indonesia menganut sistem Self Assessment sejak reformasi perpajakan tahun 1983 sampai terakhir tahun 2000 dengan diubahnya Undang-Undang Perpajakan Tersebut menjadi UU No. 16 tahun 2000, UU No. 17 Tahun 2000, UU No. 18 Tahun 2000.

\section{Kemanfaatan Nomor Wajib Pajak (NPWP)}

Nomor Pokok Wajib Pajak (NPWP) adalah nomor yang diberikan kepada wajib pajak sebagai sarana dalam administrasi perpajakan yang dipergunakan sebagai tanda pengenal diri atau identitas wajib pajak dalam melaksanakan hak dan kewajiban perpajakannya. NPWP yang dikeluarkan oleh Direktorat Jenderal Pajak merupakan satu set nomor yang terdiri dari 11 (sebelas) angka/ digit dan dikelompokkan menjadi 3 (tiga) kelompok yang tiap kelompok mempunyai arti tersendiri (Tjahjono dan Husein, 2009: 45). Nomor Pokok Wajib Pajak (NPWP) merupakan suatu sarana 
dalam administrasi perpajakan yang dipergunakan sebagai tanda pengenal diri atau identitas wajib pajak. Setiap wajib diberikan satu NPWP, dan nomor pokok wajib pajak dipergunakan untuk menjaga ketertiban dalam pembayaran pajak dan dalam pengawasan administrasi perpajakan.

\section{Kualitas pelayanan}

Parasuraman et al (1988) dalam Kartika Candra Kusuma (2014) mengemukakan 5 (lima) dimensi kualitas jasa yaitu:

\section{a) Keandalan (Reliability)}

Keandalan merupakan kemampuan untuk memberikan jasa seperti yang dijanjikan dengan akurat dan terpercaya sesuai yang diharapkan pelanggan yang tercermin dari ketepatan waktu, layanan yang sama untuk semua orang dan tanpa kesalahan.

\section{b) Ketanggapan (Responsiveness)}

Daya tanggap adalah kemampuan untuk membantu dan memberikan pelayanan yang sebaik mungkin kepada pengguna. Dimensi ini menekankan pada perhatian, kecepatan, dan ketepatan dalam menghadapi permintaan, pertanyaan, komplain dan masalah dari pengguna layanan. Daya tanggap dikomunikasikan pada konsumen melalui waktu tunggu untuk dilayani, jawaban dari pertanyaan yang mereka ajukan atau perhatian mereka terhadap masalah-masalah yang ada, juga meliputi fleksibilitas dan kemampuan untuk melayani kebutuhan pelanggan.

\section{c) Jaminan (Assurance)}

Jaminan adalah pengetahuan karyawan dan kesopanan/keramahannya, kemampuan perusahaan serta karyawannya untuk menumbuhkan rasa percaya pelanggan kepada perusahaan, yang mencakup pengetahuan, kemampuan, kesopanan, dan sifat dapat dipercaya yang dimiliki para staf, bebas dari bahaya risiko atau keragu-raguan.

\section{d) Empati (Emphaty)}

Empati merupakan perhatian tulus, caring (kepedulian), yang diberikan kepada pelanggan yang meliputi kemudahan dalam melakukan hubungan komunikasi yang baik, perhatian pribadi, dan memahami kebutuhan pelanggan. Pelanggan ingin perusahaan memahami mereka dan sangat penting bagi perusahaan mereka.

\section{e) Bukti Langsung (Tangible)}

Bukti langsung, didefinisikan sebagai penampilan fasilitas fisik, peralatan, personal, dan alat komunikasi. Semua peralatan tersebut mewakili pelayanan secara fisik atau memberikan image pelayanan yang akan digunakan oleh penguna untuk mengevaluasi kualitas.

\section{Sanksi Perpajakan}

Menurut Mardiasmo (2013) sanksi adalah pagar pembatas yang nyata bagi pelaksanaan suatu peraturan yang bermaterikan hak dan kewajiban. Sanksi merupakan wujud dari tidak dipenuhinya kewajiban yang telah ditentukan berdasarkan undang-undang maupun peraturan turunannya. Dalam undangundang perpajakan dikenal dua macam sanksi, yaitu sanksi administrasi dan sanksi pidana. Ancaman terhadap pelanggaran suatu norma perpajakan ada yang diancam dengan sanksi administrasi saja, ada yang diancam dengan sanksi pidana saja, dan ada pula yang diancam dengan sanksi administrasi dan sanksi pidana. Sanksi administrasi dikenakan terhadap pelanggar ketentuan peraturan perudang-undangan perpajakan yang akibat umumnya tidak merugikan negara. Sanksi administrasi berupa 
bunga $2 \%$ sebulan dikenakan terhadap wajib pajak yang membetulkan SPT, dikenakan SKPKB (Surat Ketetapan Pajak Kurang Bayar), tidak melunasi utang pajak pada saat jatuh tempo terlambat membayar SKPKB dan SKPKBT, mengangsur atau menunda pembayaran pajak serta menunda penyampaian SPT (Sutedi, 2011: 221).

\section{Account Representative}

Pengertian Account Representative berdasarkan Peraturan Menteri Keuangan Nomor 68/PMK.01/2008 adalah petugas yang berada di Kantor Pelayanan Pajak (KPP) yang telah melaksanakan Sistem Administrasi Modern. Account Representative (AR) berkewajiban melaksanakan pengawasan kepatuhan kewajiban perpajakan, melaksanakan bimbingan dan melaksanakan himbauan kepada Wajib Pajak (WP). Setiap Account Representative (AR) mempunyai beberapa Wajib Pajak (WP) yang harus diawasi. Penugasan pelayanan oleh Account Representative (AR) dilakukan berdasarkan jenis usaha sehingga meningkatkan profesionalisme dan meningkatkan produktivitas kerja karena pelaksanaan pekerjaan lebih terfokus.

Peran Account Representative adalah penghubung antara KPP dan wajib pajak yang bertanggung jawab untuk menyampaikan informasi perpajakan secara efektif dan profesional. Mereka dilatih untuk memberikan respons yang efektif atas pertanyaan dan permasalahan yang diajukan oleh wajib pajak setanggap mungkin. Account Representative juga bertanggung jawab agar wajib pajak juga mendapatkan haknya secara transparan, Account Representative memiliki pemahaman tentang bisnis serta kebutuhan wajib pajak dalam hubungannya dengan kewajiban perpajakannya. Untuk itu Account
Representative secara berkala mendapatkan pelatihan dan pendidikan dari berbagai narasumber Account Representative dikembangkan untuk melayani secara prima wajib pajak dengan memenuhi kebutuhan akan fasilitas yang diharapkan dan memberikan kenyamanan kepada wajib pajak (Denziana, 2015). Berdasarkan ulasan dan pendapat diatas dapat disimpulkan bahwa fungsi Account Representative yang berhubungan langsung dengan wajib pajak secara garis besar mencakup edukasi, pendampingan, dan pengawasan.

\section{HIPOTESIS PENELITIAN}

\section{Pengaruh Kemanfaatan NPWP Terhadap Kepatuhan Wajib Pajak}

Nomor Pokok Wajib Pajak (NPWP) adalah identitas diri wajib pajak dalam administrasi perpajakan, dimana satu wajib pajak akan mempunyai satu NPWP. Dengan adanya NPWP ini aparatur pajak dapat memantau kewajiban perpajakan yang harus dilakukan oleh seorang wajib pajak. Nomor Pokok Wajib Pajak juga memberi beberapa manfaat terhadap wajib pajak, seperti sebagai salah satu syarat dalam pembukaan rekening giro dan pengajuan kredit di bank. Manfaat NPWP yang diberikan kepada wajib pajak untuk memotivasi wajib pajak mendaftarkan diri dalam memperoleh NPWP dalam rangka meningkatkan kepatuhan pajak.

Menurut Nengsih dan Rahayu (2016) kemanfaatan NPWP berpengaruh positif terhadap kepatuhan wajib pajak, ini berarti bahwa semakin kepemilikan NPWP memberikan manfaat kepada wajib pajak, maka wajib pajak juga akan semakin patuh terhadap peraturan perpajakan. Wajib pajak akan menjadi sadar akan kewajiban perpajakan dan tidak melakukan perlawanan pajak yang mengarah pada kegiatan 
ketidakpatuhan. Berdasarkan penjabaran di atas, maka hipotesis pertama sebagai berikut:

H1 : Kemanfaatan Nomor Pokok Wajib Pajak (NPWP) berpengaruh positif terhadap kepatuhan wajib pajak

\section{Pengaruh Kualitas Pelayanan Terhadap Kepatuhan Wajib Pajak}

Pelayanan fiskus bertujuan untuk meningkatkan kepatuhan wajib pajak dalam menjalankan kewajibannya. Fiskus harus memberikan pelayanan prima dan memuaskan wajib pajak yang bertujuan untuk meningkatkan pengetahuan mereka pada peraturan perpajakan. Pengetahuan perpajakan berupa peraturan perundang-undangan pajak yang berlaku, hak dan kewajiban wajib pajak, sampai pada sanksi perpajakan jika mereka tidak melaksanakan kewajiban pajak. Menurut Fuadi (2013) pengaruh kualitas pelayanan pajak berpengaruh positif terhadap kepatuhan wajib pajak, pernyataan ini bermakna semakin tinggi dan tinggi kualitas pelayanan fiskus kepada wajib pajak maka akan meningkatkan kepatuhan wajib pajak.

Berdasarkan penjabaran di atas, maka hipotesis kedua sebagai berikut:

$\mathrm{H} 2$ : Kualitas pelayanan berpengaruh positif terhadap kewajiban wajib pajak

\section{Pengaruh Sanksi Pajak Terhadap Kepatuhan Wajib Pajak}

Teori atribusi berpendapat bahwa, penilaian tentang perilaku kepatuhan wajib pajak dalam melakukan kewajiban perpajakan dipengaruhi oleh salah satu penyebab eksternal yaitu sanksi pajak. Teori tersebut berpendapat adanya proses pengalaman dan pengamatan dalam menjatuhkan sanksi pajak oleh fiskus kepada wajib pajak yang melanggar kewajiban perpajakan.
Menurut Tiraada (2013) sanksi pajak berpengaruh positif terhadap kepatuhan wajib pajak. Fuadi (2013) menyatakan bahwa sanksi perpajakan berpengaruh positif terhadap kepatuhan wajib pajak. Semakin tinggi pengenaan sanksi pajak kepada wajib pajak maka akan meningkatkan kepatuhan wajib pajak. Sanksi perlu untuk diterapkan agar peraturan dan perundangundangan perpajakan tidak dilanggar. Jika kewajiban pajak tidak mentaati, maka akan ada resiko hukum yang terjadi pada wajib pajak. Resiko hukum adalah penerapan sanksi perpajakan. Penerapan tersebut berfungsi memberikan efek jera kepada wajib pajak yang melanggar kewajiban perpajakan sehingga tercipta kepatuhan wajib pajak dalam memenuhi kewajiban perpajakannya. Berdasarkan penjabaran di atas, maka hipotesis ketiga sebagai berikut:

H3 : Sanksi pajak berpengaruh positif terhadap kepatuhan wajib pajak.

\section{Pengaruh Kemanfaatan NPWP Terhadap Kepatuhan Wajib Pajak dengan Account Representative sebagai Variabel Moderasi}

Teori atribusi berpendapat bahwa, persepsi wajib pajak dalam membuat keputusan tentang perilaku kepatuhan wajib pajak dalam menjalankan kewajiban perpajakan dipengaruhi oleh penyebab internal yaitu kemanfaatan NPWP. Jika wajib pajak memperoleh pengetahuan mengenai manfaat atas kepemilikan NPWP berdasar pengamatan dan pengalaman langsung dijabarkan dalam teori pembelajaran sosial (Masuroh dan Zulaikha, 2013).

Wajib pajak ketika telah memenuhi persyaratan subyektif dan obyektif berdasarkan ketentuan peraturan perundang-undangan perpajakan wajib untuk memiliki NPWP. Pendaftaran diri dan perolehan NPWP diharapkan 
sebagai bentuk kesadaran dan suka rela wajib pajak untuk melakukannya. Namun, jika wajib pajak yang telah memenuhi persyaratan dan tidak mendaftarkan diri untuk memperoleh NPWP maka Direktorat Jendral Pajak dapat memberikan NPWP secara jabatan (Masuroh dan Zulaikha, 2013).

Penelitian yang telah dilakukan Nofri (2010) penerimaan pajak dapat ditingkatkan ketika wajib pajak patuh dan tepat waktu dalam membayar pajak, dimana kegiatan ini merupakan fungsi pengawasan oleh petugas Account Representative. Dengan dilibatkannya Account Representative diharapkan wajib pajak yang tidak patuh terhadap norma perpajakan akan semakin berkurang dan melaksanakan kewajiban perpajakannya. Selain itu Account Representative dapat menangani berbagai kasus perpajakan menjadi lebih cepat teratasi.

Peran Account Representative (AR) dapat memperkuat hubungan antara kemanfaatan NPWP dengan kepatuhan wajib pajak. Jika wajib pajak yang telah memenuhi persyaratan untuk mendaftarkan dirinya dalam memperoleh NPWP tetapi tidak dilakukan, maka AR dapat berfungsi sebagai pihak fiskus yang menerbitkan NPWP dengan jabatan. Selain itu AR juga berfungsi dalam sosialisasi tentang hak dan kewajiban wajib pajak jika sudah memiliki NPWP seperti waktu untuk pembayaran dan pelaporan. Peran AR untuk wajib pajak yang ber NPWP sebagai pihak perantara penyedia informasi peraturan perpajakan kepada wajib pajak untuk meningkatkan kepatuhan pajak.

Berdasarkan penjabaran di atas, maka hipotesis keempat sebagai berikut:

H4: Peran Account Representative memoderasi hubungan antara Kemanfaatan NPWP dengan kepatuhan wajib pajak.

\section{Pengaruh Kualitas Pelayanan Terhadap Kepatuhan Wajib Pajak dengan Account Representative sebagai Variabel Moderasi}

Kepatuhan wajib pajak dalam memenuhi kewajibannya membayar pajak berhubungan erat dengan kualitas pelayanan terbaik yang diberikan aparat pajak kepada wajib pajak. Pelayanan yang berkualitas adalah pelayanan yang dapat memberikan kepuasan kepada wajib pajak dan tetap dalam batas memenuhi standar pelayanan yang dapat dipertanggungjawabkan serta harus dilakukan secara terus-menerus (Supadmi, 2009). Apabila pelayanan yang diberikan oleh aparat pajak tidak memenuhi atau melebihi harapan wajib pajak, berarti pelayanan yang diberikan tidak berkualitas. Pelayanan yang berkualitas akan memberikan kepuasan kepada wajib pajak sehingga akan mendorong kepatuhan wajib pajak untuk memenuhi kewajiban perpajakannya kembali. Semakin baik kualitas pelayanan pajak yang diberikan oleh aparat pajak maka wajib pajak akan merasa puas sehingga wajib pajak akan menjadi patuh. Demikian pula sebaliknya, semakin buruk kualitas pelayanan pajak maka wajib pajak akan cenderung untuk tidak patuh (Masuroh dan Zulaikha, 2013).

Peran Account Representative (AR) dapat memperkuat hubungan antara kualitas pelayanan dengan kepatuhan wajib pajak. Peran Account Representative adalah penghubung antara KPP dan wajib pajak yang bertanggung jawab untuk menyampaikan informasi perpajakan secara efektif dan profesional. Mereka dilatih untuk memberikan respons yang efektif atas pertanyaan dan permasalahan yang diajukan oleh wajib pajak setanggap mungkin. Account Representative juga bertanggung jawab agar wajib pajak juga mendapatkan haknya secara transparan, 
Account Representative memiliki pemahaman tentang bisnis serta kebutuhan wajib pajak dalam hubungannya dengan kewajiban perpajakannya. Untuk itu Account Representative secara berkala mendapatkan pelatihan dan pendidikan dari berbagai narasumber Account Representative dikembangkan untuk melayani secara prima wajib pajak dengan memenuhi kebutuhan akan fasilitas yang diharapkan dan memberikan kenyamanan kepada wajib pajak (Anggrita dan Handi, 2015).

Direktorat Jenderal Pajak terus melakukan pengembangan dan perbaikan guna meningkatkan penerimaan pajak. Account Representative yang ditunjuk untuk memberikan pelayanan pajak kepada wajib pajak, juga menjalankan fungsi konsultasi. Konsultasi cukup penting karena, dengan adanya konsultasi diharapkan wajib pajak bias bertanya kepada petugas Account Representative tentang undang-undang atau peraturan perpajakan yang tidak dimengerti, sehingga terjadinya kerja sama yang baik antara wajib pajak dengan Kantor Pelayanan Pajak dimana diwakili oleh petugas Account Representative (Widomoko dan Nofriyanti, 2015). Berdasarkan penjabaran di atas, maka hipotesis kelima sebagai berikut:

H5: Peran Account Representative memoderasi hubungan antara Kualitas Pelayanan dengan kepatuhan wajib pajak

\section{Pengaruh Sanksi Pajak Terhadap Kepatuhan Wajib Pajak dengan Account Representative sebagai Variabel Moderasi}

Peran Account Representative dapat memperkuat hubungan antara sanksi pajak dengan kepatuhan wajib pajak. Dimana peran AR tersebut sebagai pihak yang mengawasi setiap wajib pajak dalam menjalankan kewajiban perpajakannya. Jika wajib pajak terindikasi tidak patuh maka AR akan menerapkan sanksi terhadap wajib pajak yang dapat berupa denda maupun hukuman. Dimana saat ini wajib pajak mempunyai pandangan jika sanksi tersebut akan memberatkan wajib pajak. Oleh karena itu daripada harus kena sanksi, wajib pajak memilih untuk patuh terhadap peraturan perpajakan dan melaksanakan kewajibannya. Sanksi perpajakan harus ada dan diterapkan untuk mendorong kewajiban perpajakan dan memberikan efek jera bagi wajib pajak yang tidak patuh. Berdasarkan penjabaran di atas, maka hipotesis keenam sebagai berikut:

H6: Peran Account Representative memoderasi hubungan antara Sanksi Pajak dengan kepatuhan wajib pajak.

\section{Kerangka Penelitian}

Berdasar atas pemaparan hipotesis diatas maka kerangka penelitian dalam penelitian ini :

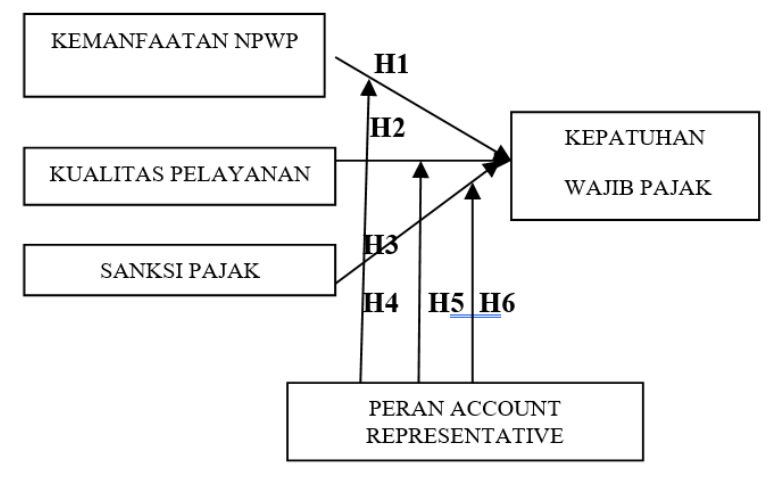

Gambar 1 Kerangka Pikir

Sumber : Data yang diolah, 2019

\section{METODE PENELITIAN}

Dalam penelitian ini penulis
menggunakan metode deskriptif
dan verifikatif dengan pendekatan
kuantitatif yang digunakan untuk
memberikan gambaran mengenai data
atau kejadian berdasarkan fakta yang
ada dengan melakukan penelitian


yang menekankan analisisnya pada data numerik. Data yang digunakan dalam penelitian ini adalah data sekunder berupa Laporan Perpajakan yang menitikberatkan pada Tingkat Kepatuhan Wajib Pajak Orang Pribadi, Kemanfaatan NPWP, Kualitas Pelayanan, Sanksi Pajak dan Peran Account Representative sebagai variable moderasi. Sampel yang digunakan untuk penelitian ini meliputi periode 2018. Teknik pengumpulan data yang digunakan yaitu metode observasi dan studi pustaka.

\section{HASIL DAN PEMBAHASAN}

\section{Hasil Uji Hipotesis}

Teknik analisis yang digunakan untuk menguji hipotesis $\mathrm{H} 1, \mathrm{H} 2$ dan $\mathrm{H} 3$ menggunakan analisis regresi berganda dengan meregresikan variabel independen (Kemanfaatan NPWP, Kualitas Pelayanan dan Sanksi Pajak) terhadap variabel dependen (kepatuhan wajib pajak), sedangkan untuk menguji hipotesis $\mathrm{H} 4, \mathrm{H} 5$ dan $\mathrm{H} 6$, menggunakan analisis moderasi dengan pendekatan absolut residual atau uji nilai selisih mutlak. Uji hipotesis ini dibantu dengan menggunakan program SPSS versi 22 .

\section{Hasil Uji Regresi Linear Berganda Hipotesis Penelitian H1, H2 dan H3}

Pengujian hipotesis $\mathrm{H} 1, \mathrm{H} 2$ dan $\mathrm{H} 3$ dilakukan dengan uji regresi linear berganda pengaruh Kemanfaatan NPWP, Kualitas Pelayanan dan Sanksi Pajak terhadap kepatuhan wajib pajak.

Tabel 4 Uji regresi berganda Coefficients $^{a}$

\begin{tabular}{|c|c|c|c|c|c|}
\hline \multirow[b]{2}{*}{ Model } & \multicolumn{2}{|c|}{$\begin{array}{l}\text { Unstandardized } \\
\text { Coefficients }\end{array}$} & \multirow{2}{*}{$\begin{array}{c}\begin{array}{c}\text { Standardized } \\
\text { Coefficients }\end{array} \\
\text { Beta }\end{array}$} & \multirow[b]{2}{*}{ t } & \multirow[b]{2}{*}{ Sig. } \\
\hline & B & $\begin{array}{l}\text { Std. } \\
\text { Error }\end{array}$ & & & \\
\hline 1 (Constant) & 1.827 & 3.175 & & .576 & .566 \\
\hline X1_KNPWP & .538 & 152 & .347 & 3.543 & .001 \\
\hline X2_KP & .055 & .099 & .054 & 2.539 & .047 \\
\hline X3_SP & .276 & 131 & .196 & 2.104 & .038 \\
\hline
\end{tabular}

a. Dependent Variable: $Y_{-}$KW
Sumber : Data yang diolah, 2019

$Y=\alpha+\beta_{1} X_{1}+\beta_{2} X_{2}+\beta_{3} X_{3}+e$

$Y=1,827+0,538 X_{1}+0,055 X_{2}+0,276 X_{3}+3,1$

75

Keterangan :

1. Nilai konstanta sebesar 1,827 menunjukkan bahwa jika variabelvariabel independen (kemanfaatan NPWP, kualitas pelayanan fiskus dan sanksi perpajakan) diasumsikan tidak mengalami perubahan (konstan) maka nilai $Y$ (kepatuhan wajib pajak) sebesar 1,827.

2. Koefisien regresi kemanfaatan NPWP sebesar 0,538 menyatakan bahwa setiap kenaikan kemanfaatan NPWP sebesar 1 poin maka akan meningkatkan kepatuhan wajib pajak sebesar 0,538.

3. Koefisien regresi kualitas pelayanan fiskus sebesar 0,055 menyatakan bahwa setiap kualitas pelayanan fiskus sebesar 1 poin maka akan meningkatkan kepatuhan wajib pajak sebesar 0,055.

4. Koefisien regresi sanksi perpajakan sebesar 0,276 menyatakan bahwa setiap sanksi perpajakan sebesar 1 poin maka akan meningkatkan kepatuhan wajib pajak sebesar 0,276.

5. Eror dalam penelitian ini adalah sebesar 3,175 yang berarti bahwa pada populasi penelitian (wajib pajak yang terdaftar di KPP Pratama Cibitung) terdapat selisih antara nilai duga dengan nilai hasil pengamatan sebesar 3,175.

Berdasarkan hasil analisis di atas, maka pembuktian hipotesis dapat dijelaskan sebagai berikut :

\section{Kemanfaatan NPWP}

Dari hasil pengujian independen sampel t-test menunjukkan nilai sig 0,001 dan nilai $t$ hitung 3,543 . Oleh karena $t$ tabel $\leq$ $\mathrm{t}$ hitung $\geq \mathrm{t}$ tabel $(1,660 \leq 3,543 \geq 1,660)$ 
dan $p$ value $<0,05$ atau $(0,001<0,05)$. Maka kesimpulannya adalah $\mathrm{H} 1$ diterima, artinya kemanfaatan NPWP berpengaruh positif terhadap kepatuhan wajib pajak.

\section{Kualitas pelayanan}

Dari hasil pengujian independen sampel T-test menunjukkan nilai sig 0,047 dan nilai t hitung 2.539. Oleh karena $t$ tabel $\leq$ $\mathrm{t}$ hitung $\geq \mathrm{t}$ tabel $(1,660 \leq 2,539 \geq 1,660)$ dan $p$ value $<0,05$ atau $(0,047<0,05)$. Maka kesimpulannya adalah $\mathrm{H} 2$ diterima, artinya kualitas pelayanan fiskus berpengaruh positif terhadap kepatuhan wajib pajak.

\section{Sanksi Pajak}

Dari hasil pengujian independen sampel T-test menunjukkan nilai 0,038 dan nilai t hitung 2,104. Oleh karena $t$ tabel $\leq t$ hitung $\geq \mathrm{t}$ tabel $(1,660 \leq 2,104 \geq 1,660)$ dan $p$ value $<0,05$ atau $(0,038<0,05)$. Maka kesimpulannya adalah H3 diterima, artinya sanksi perpajakan berpengaruh positif terhadap kepatuhan wajib pajak.

\section{Hasil Uji Koefisien Determinasi $\left(\mathbf{R}^{\mathbf{2}}\right)$}

Hasil uji koefisien determinasi pada penelitian ini adalah

Tabel 5 Uji Koefisien Determinasi $\left(R^{2}\right)$

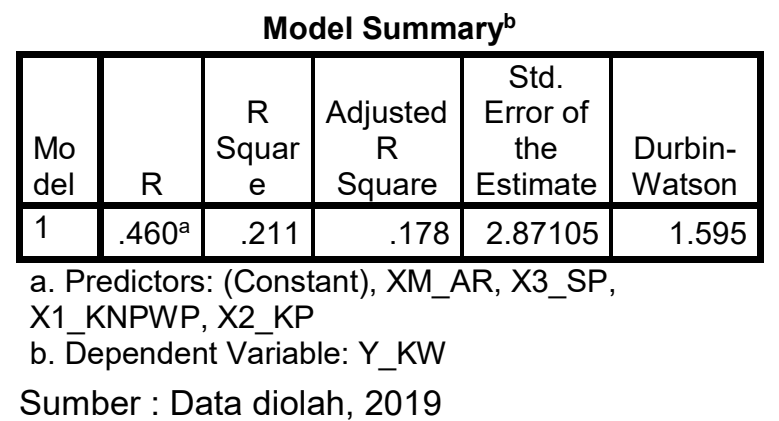

Dari hasil output pada tabel 4.16. menunjukkan besarnya nilai adjusted $\mathrm{R}^{2}$ adalah 0,178 atau $17,8 \%$ variasi kepatuhan wajib pajak dapat dijelaskan oleh variasi dari ketiga variabel independen kemanfaatan NPWP, kualitas pelayanan fiskus, dan sanksi perpajakan. Sedangkan sisanya $(100 \%$ $17,8 \%=82,2 \%$ ) dijelaskan oleh variabel lain diluar model. Nilai standar eror of the estimate (SEE) sebesar 2,871.

\section{Uji Simultan (Uji F)}

Hasil uji simultan (Uji F) pada penelitian ini adalah

Tabel 6 Uji Simultan (Uji F)

\begin{tabular}{|c|c|c|c|c|c|}
\hline \multicolumn{6}{|c|}{ ANOVA $^{a}$} \\
\hline Model & $\begin{array}{l}\text { Sum of } \\
\text { Squares }\end{array}$ & df & $\begin{array}{c}\text { Mean } \\
\text { Square }\end{array}$ & $\mathrm{F}$ & Sig. \\
\hline 1 Regression & 196.593 & 3 & 65.531 & 7.899 & $.000^{b}$ \\
\hline Residual & 796.447 & 96 & 8.296 & & \\
\hline Total & 993.040 & 99 & & & \\
\hline
\end{tabular}

a. Dependent Variable: $Y \mathrm{KW}$

b. Predictors: (Constant), X3_SP, X2_KP, X1_KNPWP

Sumber : Data diolah, 2019

Dari hasil output diatas bahwa nilai F hitung sebesar 7,899 jika dibandingkan dengan $\mathrm{F}$ tabel pada tingkat signifikansi $5 \%$ yaitu 2,70 maka nilai $F$ hitung lebih besar dari $F$ tabel $(7,899>2,70)$, artinya bahwa kemanfaatan NPWP, kualitas pelayanan fiskus dan sanksi perpajakan secara bersama-sama berpengaruh terhadap kepatuhan wajib pajak.

\section{Hasil Uji Regresi Moderasi dengan Pendekatan Nilai Selisih Mutlak Terhadap Hipotesis Penelitian H4, H5 dan $\mathrm{H} 6$}

Langkah uji nilai selisih mutlak dalam penelitian ini dapat digambarkan dengan persamaan regresi sebagai berikut:

$Y=\alpha+\beta 1 . Z X 1+\beta 2 . Z X 2+\beta 3 . Z X 3+$ $\beta 4 \cdot Z M+\beta 5 \cdot[Z X 1-Z M]+\beta 6 \cdot[Z X 2-Z M]+$ $\beta 7 .[Z X 3-Z M]+e$

$\begin{array}{ccc}\text { Untuk } & \begin{array}{c}\text { mengetahui } \\ \text { variabel }\end{array} & \begin{array}{c}\text { bagaimana } \\ \text { Account }\end{array}\end{array}$


Representative atas pengaruh Kebermanfaatan NPWP, Kualitas Pelayanan dan Sanksi Pajak terhadap kepatuhan wajib pajak.

Tabel 7 Regresi dengan Interaksi Menggunakan Uji Nilai Selisih Mutlak

\begin{tabular}{|c|c|c|c|c|c|}
\hline \multicolumn{6}{|c|}{ Coefficients $^{a}$} \\
\hline \multirow[b]{2}{*}{ Model } & \multicolumn{2}{|c|}{$\begin{array}{c}\text { Unstandardized } \\
\text { Coefficients }\end{array}$} & \multirow{2}{*}{$\begin{array}{c}\text { Standardize } \\
d \\
\text { Coefficients } \\
\text { Beta }\end{array}$} & \multirow[b]{2}{*}{$t$} & \multirow[b]{2}{*}{ Sig. } \\
\hline & B & $\begin{array}{l}\text { Std. } \\
\text { Error }\end{array}$ & & & \\
\hline $\begin{array}{ll} & \text { (Constan } \\
\text { t) }\end{array}$ & $\begin{array}{r}26.39 \\
0\end{array}$ & 25.238 & & -1.046 & .298 \\
\hline $\begin{array}{l}\text { X1_KNP } \\
W P\end{array}$ & .261 & 1.343 & .168 & .195 & .846 \\
\hline $\mathrm{X} 2 \_\mathrm{KP}$ & 187 & .794 & 182 & .236 & .814 \\
\hline X3_SP & 1.944 & 1.054 & 1.383 & 1.845 & .068 \\
\hline XM_AR & 1.987 & 1.680 & 1.124 & 1.183 & .040 \\
\hline $\mathrm{X} 1 . \mathrm{XM}$ & .014 & .089 & .235 & .163 & .871 \\
\hline $\mathrm{X} 2 . \mathrm{XM}$ & .011 & .053 & .227 & .200 & .042 \\
\hline X3.XM & .112 & .070 & 1.592 & 1.588 & .116 \\
\hline
\end{tabular}

Sumber : Data diolah, 2019

Hasil interpretasi dari hipotesis penelitian $(\mathrm{H} 4, \mathrm{H} 5$, dan $\mathrm{H} 6)$ yang diajukan dapat dilihat sebagai berikut:

Account Representative memoderasi hubungan antara Kemanfaatan NPWP dengan kepatuhan wajib pajak ( $\mathrm{H} 4)$

Diperoleh nilai signifikan uji $t$ variabel account representative sebesar 0,040 . Nilai tersebut kurang dari 0,05 yang berarti bahwa terdapat pengaruh variabel account representative terhadap kepatuhan wajib pajak. Selanjutnya pada regresi dengan interaksi diperoleh nilai signifikansi interaksi Kemanfaatan NPWP dan Account Representative sebesar 0,871 yang menunjukkan bahwa interaksi tersebut tidak berpengaruh. Karena koefisien b2 signifikan dan b3 tidak signifikan, maka penggunaan variabel Account Representative termasuk dalam kategori prediktor yang artinya bahwa variabel Account Representative merupakan variabel independen dan tidak termasuk ke dalam variabel moderasi.

Hasil uji nilai selisih mutlak yang terlihat pada tabel 7 menunjukkan bahwa variabel moderating X1.XM memiliki $t$ hitung sebesar $0,163<1,660$ dengan tingkat signifikan $0,871>5 \%(\alpha=0,05)$. Nilai koefisien moderat antara variabel Kebermanfaatan NPWP dengan Account Representative 0,163. Koefisien regresi ini berarti Account Representative memperlemah

Kebermanfaatan NPWP terhadap kepatuhan wajib pajak $\mathrm{Hal}$ ini berarti bahwa account representative bukan merupakan variabel moderasi yang memperkuat atau memperlemah hubungan variabel kebermanfaatan NPWP dengan kepatuhan wajib pajak. Jadi H4 yang menyatakan account representative dapat memoderasi hubungan antara kebermanfaatan NPWP dengan kepatuhan wajib pajak ditolak.

Account Representative memoderasi hubungan antara Kualitas Pelayanan dengan kepatuhan wajib pajak (H5)

Diperoleh nilai signifikan uji $t$ variabel account representative sebesar 0,040 . Nilai tersebut kurang dari 0,05 yang berarti bahwa terdapat pengaruh variabel account representative terhadap kepatuhan wajib pajak. Selanjutnya pada regresi dengan interaksi diperoleh nilai signifikansi interaksi kualitas pelayanan dan pelayanan fiskus sebesar 0,042 yang menunjukkan bahwa interaksi tersebut berpengaruh. Karena koefisien b2 signifikan dan b3 signifikan, maka penggunaan variabel account representative termasuk dalam kategori quasi moderasi yang artinya bahwa variabel account representative merupakan variabel yang mampu memoderasi hubungan antara variabel kualitas pelayanan terhadap kepatuhan 
wajib pajak dan sekaligus menjadi variabel independen.

Dari hasil uji nilai selisih mutlak yang terlihat pada tabel 7 menunjukkan hasil bahwa variabel moderating X2.XM mempunyai t-hitung sebesar $0,200>t$ table 1,660 dan tingkat signifikansi 0,042 $<5 \%(\alpha=0,05)$. Hal ini berarti bahwa variabel account representative merupakan variabel yang memperkuat hubungan variabel kualitas pelayanan terhadap kepatuhan wajib pajak. Jadi H5 yang menyatakan bahwa account representative memoderasi hubungan antara kualitas pelayanan dengan kepatuhan wajib pajak diterima.

Account Representative memoderasi hubungan antara Sanksi Pajak dengan kepatuhan wajib pajak ( $\mathrm{H6}$ )

Diperoleh nilai signifikan uji $t$ variabel account representative sebesar 0,040 . Nilai tersebut kurang dari 0,05 yang berarti bahwa terdapat pengaruh variabel account representative terhadap kepatuhan wajib pajak. Selanjutnya pada regresi dengan interaksi diperoleh nilai signifikansi interaksi sanksi pajak dan pelayanan fiskus sebesar 0,116 yang menunjukkan bahwa interaksi tersebut tidak berpengaruh. Karena koefisien b2 signifikan dan b3 tidak signifikan, maka penggunaan variabel Account Representative termasuk dalam kategori prediktor yang artinya bahwa variabel Account Representative merupakan variabel independen dan tidak termasuk ke dalam variabel moderasi.

Dari hasil uji nilai selisih mutlak yang terlihat pada tabel 7 menunjukkan hasil bahwa variabel moderating X3.XM mempunyai t-hitung sebesar $1,588>t$ table 1,660 dan tingkat signifikansi 0,116 $>5 \%(\alpha=0,05)$. Hal ini berarti bahwa variabel account representative merupakan variabel yang memperlemah hubungan variabel sanksi pajak terhadap kepatuhan wajib pajak. Jadi $\mathrm{H} 6$ yang menyatakan bahwa account representative memoderasi hubungan antara sanksi pajak dengan kepatuhan wajib pajak ditolak.

\section{Hasil Uji Koefisien Determinasi $\left(\mathbf{R}^{2}\right)$}

Tabel 8 Uji Koefisien Determinasi $\left(R^{2}\right)$ Model Summary

\begin{tabular}{|l|c|r|r|c|}
\hline Model & $\mathrm{R}$ & $\begin{array}{c}\mathrm{R} \\
\text { Square }\end{array}$ & $\begin{array}{c}\text { Adjusted } \mathrm{R} \\
\text { Square }\end{array}$ & $\begin{array}{c}\text { Std. Error } \\
\text { of the } \\
\text { Estimate }\end{array}$ \\
\hline 1 & $.483^{\mathrm{a}}$ & .233 & .175 & 2.87660 \\
\hline
\end{tabular}

a. Predictors: (Constant), X3.XM, X2_KP, X1_KNPWP, XM_AR, X3_SP, X2.XM, X1.XM

Sumber : Data diolah, 2019

Berdasarkan Hasil uji koefisien determinasi, nilai $\mathrm{R}^{2}$ (Adjusted $R$ Square) sebesar 0,175. Hal ini berarti $17,5 \%$ kepatuhan wajib pajak dipengaruhi oleh variabel X3.XM, X2_KP, X1_KNPWP, XM_AR, X3_SP, X2.XM, X1.XM, sedangkan sisanya sebesar $82,5 \%$ dipengaruhi oleh variabel lain yang belum diteliti dalam penelitian ini.

\section{Uji Simultan (Uji F)}

Tabel 9 Uji Simultan (Uji F) ANOVA $^{a}$

\begin{tabular}{|c|r|c|c|c|c|}
\hline \multicolumn{1}{|c|}{ Model } & $\begin{array}{r}\text { Sum of } \\
\text { Square } \\
\text { s }\end{array}$ & df & $\begin{array}{c}\text { Mean } \\
\text { Square }\end{array}$ & F & Sig. \\
\hline $1 \quad \begin{array}{r}\text { Regressi } \\
\text { on }\end{array}$ & $\begin{array}{r}231.75 \\
5\end{array}$ & 7 & 33.108 & 4.001 & $.001^{\mathrm{b}}$ \\
Residual & $\begin{array}{r}761.28 \\
5\end{array}$ & 92 & 8.275 & & \\
& & & & \\
Total & $\begin{array}{r}993.04 \\
0\end{array}$ & 99 & & & \\
\hline
\end{tabular}

a. Dependent Variable: $Y_{-} \mathrm{KW}$

b. Predictors: (Constant), X3.XM, X2_KP, X1_KNPWP, XM_AR, X3_SP, X2.XM, X1.XM

Sumber : Data diolah, 2019

Hasil Anova atau F Tes menunjukkan bahwa nilai F-hitung sebesar 4,001 dengan tingkat signifikansi 0,001 jauh dibawah 0,05. Hal ini berarti bahwa variable X3.XM, X2_KP, X1_KNPWP, XM_AR, X3_SP, $\mathrm{X} 2 . \overline{X M}, \mathrm{X} 1 . \overline{X M}$ secara bersama-sama 
atau simultan mempengaruhi kepatuhan wajib pajak.

\section{PEMBAHASAN}

\section{Pengaruh Kebermanfaatan NPWP terhadap Kepatuhan Wajib Pajak}

Hipotesis pertama $(\mathrm{H} 1)$ yang menyatakan bahwa Kemanfaatan NPWP berpengaruh positif dan signifikan terhadap kepatuhan wajib pajak. Hasil penelitian menunjukkan bawa koefisien regresi sebesar 3,543 dan nilai signifikansi sebesar 0,001. Berdasarkan hasil analisis menunjukkan bahwa Kemanfaatan NPWP berpengaruh positif dan signifikan terhadap kepatuhan wajib pajak. Hasil statistik deskriptif kemanfaatan NPWP menunjukkan bahwa jawaban sebagian besar responden adalah setuju. Hal ini berarti bahwa kepemilikan NPWP dirasakan bermanfaat bagi Wajib Pajak Orang Pribadi yang berpenghasilan di Kabupaten Bekasi..

Hasil penelitian ini mengindikasikan bahwa dengan memiliki NPWP, wajib pajak orang pribadi akan termotivasi untuk patuh dalam melaksanakan kewajiban pembayaran dan pelaporan pajaknya. Kepemilikan NPWP ini pada dasarnya diwajibkan pada wajib pajak yang telah memenuhi persyaratan, hal ini supaya pemerintah dapat mengawasi kepatuhan wajib pajak. Agar wajib pajak mempunyai kesadaran dalam mendaftarkan diri untuk memperoleh NPWP maka diperlukan peran pemerintah dalam sosialisasi akan manfaat NPWP ini kepada wajib pajak.

\section{Pengaruh Kualitas Pelayanan terhadap Kepatuhan Wajib Pajak}

Hipotesis kedua (H2) yang menyatakan bahwa Kualitas Pelayanan berpengaruh positif dan signifikan terhadap kepatuhan wajib pajak. Hasil analisis menunjukkan bawa koefisien regresi sebesar 2,539 dan nilai signifikansi sebesar 0,047. Berdasarkan hasil analisis menunjukkan bahwa Kualitas Pelayanan berpengaruh positif dan signifikan terhadap kepatuhan wajib pajak. Hasil statistik deskriptif kualitas pelayanan menunjukkan bahwa jawaban sebagian besar responden adalah setuju. Hal ini berarti bahwa wajib pajak orang pribadi yang berpenghasilan yang terdaftar di KPP Pratama Cibitung berpendapat bahwa kualitas pelayanan yang disajikan oleh aparatur fiskus kepada wajib pajak dinilai baik.

Hasil penelitian ini mengindikasikan bahwa kualitas pelayanan dapat meningkatkan kepatuhan wajib pajak dalam melaksanakan kewajiban membayar dan melaporkan pajaknya. Hal ini dapat terjadi karena kualitas pelayanan dari aparat pajak dapat memenuhi atau melebihi harapan wajib pajak. Aparat pajak terus berupaya meningkatkan pelayanan melalui perkembangan teknologi informasi dengan tersedianya fasilitas e-SPT dan e-filling. Walaupun belum sepenuhnya efektif tetapi dapat memudahkan wajib pajak. Semakin banyaknya wajib pajak yang sudah memahami bagaimana menggunakan e-SPT dan e-filling karena seringnya sosialisasi perpajakan yang dilakukan oleh fiskus. Aparat pajak perlu melakukan strategi khusus untuk terus meningkatkan kualitas pelayanan sehingga dapat meningkatkan kepatuhan WP OP yang melakukan usaha di Kabupaten Bekasi.

\section{Pengaruh Sanksi Pajak terhadap Kepatuhan Wajib Pajak}

Hipotesis ketiga (H3) yang menyatakan bahwa Sanksi Pajak berpengaruh positif dan signifikan terhadap kepatuhan wajib pajak. Hasil analisis menunjukkan bawa koefisien regresi sebesar 2,104 dan nilai signifikansi sebesar 0,038. Berdasarkan 
hasil analisis menunjukkan bahwa Sanksi Pajak berpengaruh positif dan signifikan terhadap kepatuhan wajib pajak. Hasil statistik deskriptif sanksi perpajakan menunjukkan bahwa jawaban sebagian besar responden adalah netral. Hal ini berarti bahwa wajib pajak orang pribadi yang berpenghasilan yang terdaftar pada kpp pratama cibitung berpendapat sanksi pajak yang diberikan aparatur fiskus kepada wajib pajak yang tidak melaksanakan kewajiban perpajakan dinilai netral.

Hasil penelitian ini mengindikasikan bahwa sanksi pajak dapat meningkatkan kepatuhan wajib pajak. Hal ini dikarenakan karena sanksi pajak yang diberlakukan pemerintah fiskus kepada wajib pajak dinilai lebih berat jika dibandingkan dengan melakukan kewajiban perpajakan sehingga wajib pajak lebih memilih untuk patuh daripada melaksanakan sanksi perpajakan. Aparatur fiskus sebaiknya memberikan pengetahuan perpajakan akan sanksi pajak ini kepada wajib pajak melalui sosialisasi. Penerapan sanksi perpajakan terhadap wajib pajak yang melanggar peraturan perpajakan ini juga harus dilaksanakan tanpa pandang bulu dan dilakukan secara konsisten.

\section{Account Representative Memoderasi Hubungan Antara Kemanfaatan NPWP dengan Kepatuhan Wajib Pajak}

Hipotesis keempat (H4) yang menyatakan account representative dapat memoderasi hubungan antara kebermanfaatan NPWP dengan kepatuhan wajib pajak ditolak. Dari hasil penelitian variabel Account Representative termasuk dalam kategori prediktor yang artinya bahwa variabel Account Representative merupakan variabel independen dan tidak termasuk ke dalam variabel moderasi.

Hasil penelitian ini mengindikasikan bahwa account representative tidak dapat memoderasi variabel kemanfaatan NPWP wajib pajak untuk patuh melaksanakan kewajiban perpajakannya. Hal ini dapat terjadi karena kinerja dari account representative belum dapat memenuhi atau melebihi harapan wajib pajak dalam hal kemanfaatan NPWP. Adanya pelayanan dan komunikasi account representative yang kurang memuaskan kepada wajib pajak saat memberikan informasi akan manfaat dan pentingnya NPWP, membuat kepercayaan wajib pajak kepada aparat pajak menjadi turun. Account Representative terus berupaya meningkatkan pelayanan melalui perkembangan teknologi informasi dengan tersedianya fasilitas e-SPT dan e-filling. Namun, hal ini masih belum sepenuhnya efektif dan belum dapat memudahkan wajib pajak. Masih banyak wajib pajak yang belum memahami bagaimana menggunakan e-SPT dan efilling karena untuk mengisi formulir SPT manual saja masih banyak yang kesulitan. Selain itu, keterbatasan Sumber Daya Manusia (SDM) dan fasilitas yang dimiliki oleh wajib pajak menjadi hambatan untuk dapat mengaksesnya. Account representative perlu melakukan strategi khusus untuk mengatasi permasalahan tersebut sehingga dapat meningkatkan kepatuhan WP OP.

\section{Account Representative Memoderasi Hubungan Antara Kualitas Pelayanan dengan Kepatuhan Wajib Pajak}

Hipotesis kelima (H5) yang menyatakan account representative dapat memoderasi hubungan antara kualitas pelayanan dengan kepatuhan wajib pajak diterima. Dari hasil penelitian variabel account representative termasuk dalam kategori quasi moderasi yang artinya bahwa variabel account representative merupakan variabel yang mampu memoderasi hubungan antara 
variabel kualitas pelayanan terhadap kepatuhan wajib pajak dan sekaligus menjadi variable independen.

Hasil penelitian ini mengindikasikan bahwa account representative dapat memoderasi variabel kualitas pelayanan kepada wajib pajak untuk patuh melaksanakan kewajiban perpajakannya. Hal ini dapat terjadi karena Kualitas pelayanan menjadi kunci bagi aparat untuk meningkatkan penerimaan pajak dan kepuasan wajib pajak terhadap kinerja Account Representative. Kualitas pelayanan memiliki hubungan yang erat dengan kepatuhan wajib pajak, kualitas pelayanan akan memberikan suatu dorongan kepada wajib pajak untuk menjalin suatu hubungan yang dinamis dengan Kantor Pelayanan Pajak (KPP). Account Representative dapat mengawasi dan mengingatkan wajib pajak tentang pajak yang dikenakan terhadap wajib pajak, hal ini akan berakibat pada kepatuhan wajib pajak tersebut untuk membayarkan kewajibannya yaitu membayar pajak. Seorang Account Representative memberikan konsultasi tentang perpajakan yang dihadapi oleh wajib pajak.

\section{Account Representative Memoderasi Hubungan Antara Sanksi Pajak dengan Kepatuhan Wajib Pajak.}

Hipotesis keenam (H6) yang menyatakan account representative dapat memoderasi hubungan antara sanksi pajak dengan kepatuhan wajib pajak ditolak. Dari hasil penelitian variabel Account Representative termasuk dalam kategori prediktor yang artinya bahwa variabel Account Representative merupakan variabel independen dan tidak termasuk ke dalam variabel moderasi.

Hasil penelitian ini mengindikasikan bahwa account representative tidak dapat memoderasi variabel sanksi pajak untuk patuh melaksanakan kewajiban perpajakannya. Hal ini dapat terjadi karena pengetahuan wajib pajak yang minim mengenai sanksi perpajakan. Pemberian sanksi yang memberatkan wajib pajak bertujuan untuk memberikan efek jera sehingga tercipta kepatuhan pajak. Namun, pengetahuan wajib pajak yang minim mengenai sanksi perpajakan dapat membuat wajib pajak beranggapan bahwa sanksi bukan hal yang menakutkan atau memberatkan sehingga dapat mencegah terjadinya ketidakpatuhan.

\section{PENUTUP}

Berdasarkan hasil analisis dan pembahasan tentang pengaruh kemanfaatan NPWP, kualitas pelayanan fiskus dan sanksi perpajakan terhadap kepatuhan wajib pajak studi pada wajib pajak yang terdaftar di KPP Pratama Cibitung dengan Peran Account Representative sebagai Variabel Moderasi, maka dapat ditarik kesimpulan sebagai berikut:

1. Kemanfaatan nomor pokok wajib pajak (NPWP) berpengaruh positif dan signifikan terhadap kepatuhan wajib pajak untuk membayar pajak.

2. Kualitas pelayanan fiskus berpengaruh positif dan signifikan terhadap kepatuhan wajib pajak untuk membayar pajak.

3. Sanksi pajak berpengaruh positif dan signifikan terhadap kepatuhan wajib pajak untuk membayar pajak.

4. Account representative dapat memoderasi hubungan antara kebermanfaatan NPWP dengan kepatuhan wajib pajak ditolak. Account Representative termasuk dalam kategori prediktor yang artinya bahwa variabel Account Representative merupakan variabel independen dan tidak termasuk ke dalam variabel moderasi.

5. Account representative dapat memoderasi hubungan antara kualitas 
pelayanan dengan kepatuhan wajib pajak diterima. Account representative termasuk dalam kategori quasi moderasi yang artinya bahwa variabel account representative merupakan variabel yang mampu memoderasi hubungan antara variabel kualitas pelayanan terhadap kepatuhan wajib pajak dan sekaligus menjadi variabel independen.

6. Account representative dapat memoderasi hubungan antara sanksi pajak dengan kepatuhan wajib pajak ditolak. Account Representative termasuk dalam kategori prediktor yang artinya bahwa variabel Account Representative merupakan variabel independen dan tidak termasuk ke dalam variabel moderasi.

Saran penulis untuk penelitian yang lebih lanjut dan untuk KPP Pratama Cibitung untuk meningkatkan kinerjanya dalam rangka untuk meningkatkan penerimaan dan kepatuhan pajak adalah

1. Saran Teoritis

a. Bagi para peneliti lain yang ingin melakukan penelitian sejenis, hendaknya memperhatikan responden jika hendak menggunakan metode survei. Karena Karakteristik data yang diperoleh hanya terbatas pada wajib pajak yang aktif dalam pelaporan perpajakan yang sering bimbingan dan konsultasi dengan account representative. Wajib pajak ini tentu mempunyai pemahaman yang baik tentang perpajakan.

b. Peneliti lain juga hendaknya memperhatikan hal-hal lain yang mempengaruhi tingkat kepatuhan wajib pajak, seperti realisasi penerimaan, tingkat penyampaian SPT Tahunan, jumlah wajib pajak efektif, dan lain-lain.

2. Saran Praktis a. Salah satu upaya dalam rangka meningkatkan kepatuhan wajib pajak adalah dengan pelayanan prima terhadap wajib pajak. Kantor Pelayanan Pajak harus tetap menjaga dan meningkatkan kualitas pelayanan terhadap wajib pajak. Direktorat Jenderal Pajak perlu menetapkan standar kualitas pelayanan prima, seperti : tata cara menyapa, tata cara menyampaikan informasi, dan lain-lain.

b. Direktorat Jenderal Pajak pajak sebaiknya secara terus menerus melakukan inovasi dalam pelayanan sehingga dapat merangkul dan memberikan pemahaman yang baik kepada masyarakat yang apatis dan cenderung tidak paham dalam perpajakan.

c. Direktorat Jenderal Pajak sebaiknya berkoordinasi dengan instansiinstansi lain dalam mengawasi pemenuhan perpajakan wajib pajak.

Keterbatasan yang ditemui dalam penelitian ini adalah:

a. Sedikitnya wajib pajak dan waktu yang singkat sehingga kurang dapat menggambarkan persepsi wajib pajak secara utuh terhadap penelitian hasil konkret dari kinerja account representative. Peneliti mengharapkan untuk peneliti setelah ini untuk mencakup tempat yang lebih luas dan menjangkau dari semua karakteristik yang ada.

b. Penelitian ini hanya menggunakan sampel pada satu KPP Pratama Cibitung, sehingga tidak dapat mencerminkan karakteristik responden daerah lain, karena perilaku dan persepsi wajib pajak sangat erat dengan karakteristik wilayahnya.

c. Sampel tidak memisahkan antara wajib pajak orang pribadi, wajib pajak badan, dan wajib pajak bendahara. 
Hal ini di sebabkan penelitian ini masih merupakan penelitian untuk memberikan fenomena yang ada dari gambaran umumnya saja.

\section{DAFTAR PUSTAKA}

Anggraini, Puspita dan Feri Prasetyo. 2014. E-Filling Sebagai Peran Indonesia dalam Memberikan Apresiasi dan Kontribusi Mendukung Komunitas ASEAN dalam Kemudahan Pelayanan Pajak. Jurnal Khatulistiwa. Vol. 2, No. 2, Hal: 1-11.

Brata, Januar D,. 2017. Pengaruh Kesadaran wajib pajak, pelayanan fiskus dan sanksi pajak terhadap kepatuhan wajib pajak orang pribadi yang melakukan kegiatan usaha dan pekerjaan bebas di kota Samarinda. Forum ekonomi Vol. 19 No.1.

Christover, Arnold Putra. 2016. Pemahaman Ekstensifikasi Wajib Pajak dan Intensifikasi Pajak terhadap Prsepsi Fiskus tentang Penerimaan Pajak. Jurnal EMBA. Vol. 4, No. 1, Hal: 1241-1253.

Farikha, Intan. 2016. Sosialisasi Peraturan Perpajakan dan Kinerja Account Representative kairan dengan Kepatuhan Wajib Pajak. Jurnal Ilmu dan Riset Akuntansi. Vol. 5, No. 3, Hal: 1-17.

Fuadi, Arabella O., Mangitong Y. 2013. Pengaruh kualitas pelayanan pajak, sanksi perpajakan dan biaya kepatuhan pajak terhadap kepatuhan wajib pajak UMKM. Program akuntansi pajak program akuntansi universitas Kristen petra. Tax Accounting \& review. Vol. 1 No. 1
Ghozali, Imam. Aplikasi Analsis Mutivariate dengan Program IBM SPSS 21. Universitas Diponegoro. Semarang. 2013.

Ghozali, Imam. 2016. Aplikasi analisis multivariatedengan program spss. Vol. ke VIII: Badan penerbit Universitas Diponegoro

Irawan, Rahmawati dan Arja Sadjiarto. 2014. Pengaruh Account Representative terhadap Kepatuhan Wajib Pajak. Jurnal Tax and Accounting. Vol. 4, No. 2, Hal: 1-13.

Jotopurnomo, Cindy.,\& Mangoting, Y. 2013. Pengaruh kesadaran wajib pajak, kualitas pelayanan fiskus, sanksi perpajakan, lingkungan wajib pajak terhadap kepatuhan wajib pajak orang pribadi di Surabaya. Tax Accounting \& Review, Vol. 1 No. 1

Masruroh, siti. 2013. Pengaruh kemanfaatan NPWP, Kualitas pelayanan, sanksi perpajakan terhadap kepatuhan wajib pajak (Studi empiris pada WP OP di kabupaten Tegal. Fakultas Ekonomika dan bisnis Universitas Diponegoro. E-jurnal Vol.2 No.4 Tahun 2013. Hal 1-15

Mintje, Megahsari Septiani. 2016. Pengaruh sikap, kesadaran dan pengetahuan terhadap kepatuhan wajib pajak orang pribadi dalam memiliki NPWP (studi kasus pada wajib pajak orang pribadi pemilik UMKM yang terdaftar di KPP Pratama Manado). Jurnal EMBA Vol.4 No.1 Maret 2016 Hal. 10311043

Muzaki, Ahmad Faozan. 2014. Kesadaran wajib pajak, pelayanan 
fiskus dan sanksi perpajakan terhadap kepatuhan wajib pajak (Studi kasus di KPP Pratama Kota Tegal). Fakultas ekonomi Universitas Muhammadiyah Purwokerto. E-Jurnal akuntansi Vol XII No. 1.

Pandiangan, Liberti. 2008. Modernisasi dan Reformasi Pelayanan Perpajakan.

Jakarta: PT. Elex Media Komputindo.

Purnaditya, Riano R,. 2015. Pengaruh pemahaman pajak , kualitas pelayanan, dan sanksi pajak terhadap kepatuhan wajib pajak (Studi empiris WP OP yang melakukan Usaha di KPP Pratama Semarang Candisari). Fakultas ekonomika dan Bisnis Universitas Diponegoro. E-jurnal Vol.4 No.4 Tahun 2015. Hal. 1-11

Rahmawati, Sri. 2015. Pengaruh kemanfaatan NPWP, Kualitas pelayanan, dan Kesadaran wajib pajak terhadap Kepatuhan wajib pajak orang pribadi. Jom FEKON Vol. 2 NO. 2.

Resmi, Siti. 2014. Perpajakan: Teori dan Kasus. Jakarta: Salemba empat

Sugiyono. 2017. Metode penelitian kuantitatif, kualitatif, dan R\&D. Bandung: Alfabet

Tene, Johanes Herbert. 2017. Pengaruh pemehaman wajib pajak, kesadaran wajib pajak, sanksi perpajakan dan pelayanan fiskus terhadap kepatuha wajib pajak (studi empiris pada wp-op yang terdaftar di KPP Pratama Manado). Jurnal EMBA Vol.5, Hal. 443-453.
Tiraada, Tryana A.M. 2013. Kesadaran perpajakan, sanksi pajak, sikap fiskus terhadap kepatuhan WPOP di Kabupaten Minahasa selatan. Jurnal EMBA Vol. 1 No. $3 \mathrm{Hal}$. 999-1008

Winerungan, Oktaviane L,. 2013. Sosialisasi perpajakan, pelayanan fiskus, dan sanksi perpajakan WP OP di KPP Manado dan KPP Bitung. Jurnal EMBA Vol. 1 No.3. Hal 960-970

Widomoko dan Novryanti. 2017. Pengaruh Kualitas Pelayanan, Pengawasan, dan Konsultasi Oleh Account Representative (AR) terhadap Kepatuhan Wajib Pajak. Jurnal Renaissance. Vol. 2, No. 1, Hal: 132-146. 